\title{
The Enduring Legend of Grace Kelly
}

\author{
By Joan Fox
}

Spring 1994 Issue of KINEMA

FEW FEMALE STARS of the fifties have joined the legendary immortals of the American cinema. There were many beauties then and some great magnetic stars like Doris Day. Yet only the mysterious extrovert, Marilyn Monroe, and the mysterious introvert, Grace Kelly, shone with a brighter light.

Like Monroe, Grace Kelly captured the imagination of future generations. There is public and media fascination with Princess Grace and everything that touched her. There have been rumours of a cult adoration in Monaco which has sought to have her enrolled in the first declension toward sainthood. The tabloid rags have it that she did not die but was so badly shattered in her fatal accident that her family had her put away in a secret place. But, because she is a kind soul, she has ventured forth to a hidden rendezvous with Jack Kennedy in his secret place to comfort the brain-damaged former President. They held hands. This is a charming conceit of the popular mind, worthy of the ancient Greek kings and goddesses meeting in the eternally present afterlife.

As a screen goddess in the mid-fifties, she was admired by women and adored by men. Hard-nosed antifeminist Anthony Burgess, who knew her in real life, wrote of her with awe and affection to the point of reverence. Her screen career lasted only five years before she married a real-life prince and sailed away to rescue the Grimaldis and their small principality from the clutches of Charles de Gaulle. She became as loved by her somewhat cynical subjects as she had been by her directors, leading men, and fans. The worst that was ever said of her, on and off the screen, was that she could occasionally be very stuffy and sometimes, when dolorous, loved champagne too much.

She was the feminine ideal of the fifties, an ideal now much misunderstood or maligned, but one of considerable merit nonetheless. Her seductive allure was centred in her firm certainty of the high value of the female force. Her sincere Catholicism seems to have produced in her a powerful sense of personal worth. Her German-Irish parents gave her the paradoxical qualities of determined self-control and smiling spontaneity. But she was first and foremost an American idol: intelligent, independent, and determined to get what she wanted within the status quo.

America had come out of the Second World War as the richest, most powerful nation on earth, indeed the only solvent entity. Willy nilly, America had greatness thrust upon her. At the same time she was the inheritor of imperial responsibilities and the hope of the world. Grace Kelly's firm persona was above all a model for American women about to face the new era as wives of a proconsular elite, an American aristocracy newly concerned with "class". She taught her lesson by sketching the impeccable façade of the Roman Matron. Like Caesar's wife, she was above reproach while redefining the virtuous qualities of the Good Wife. Loyal and true-blue, reliable and affectionate through sickness and health, through richness and danger.

Marriage was her game in even the raciest of roles. The rogues, rascals, and lone wolves she seduced on the screen needed a Good Woman to settle them down. The implicit message to war veterans and women alike was that domesticity was the highest goal in life. Those restless heroes needed to be reminded that home and hearth were the proper responsibilities of civilian life.

Her beauty, which she wore as her due, was of the old world, pink-and-white Dresden porcelain kind, united with the slender, long-boned delicacy of the free-swinging, athletic American frame. The strong underlying bone structure of her face meant that her beauty registered photographically despite her pale fairness. Blondes had ruled supreme in black and white films but faded from eminence in early colour where the camera loved brunettes like Vivien Leigh, Elizabeth Taylor, Ava Gardner, or Audrey Hepburn.

Her screen image was also rivetting because of the gracefulness of her movements. She never struck an awkward note with her hands, gestures, or posture in repose; and in movement she matched Cary Grant. Natural gracefulness (i.e. "bearing") is an innate but hard-won gift. Another quality which made her allure 
plangent and indefinable was her low melodious voice. She achieved this tone after a false start of brittle, elocution-style, school-girl diction that made one wince. Her voice could range from a small apprehensive breathiness like Monroe or Jackie 0nassis to the clipped crispness of Katharine Hepburn. She had a limited tonal range but a soft, throaty contralto lay underneath ever utterance. Since the contralto is the most compelling of female voices to the male ear, this marked her as a seductress despite all her behaviour to the contrary.

There is a consistency and tempo to the screen roles of most great movie stars which signals their personality to the audience. Grace Kelly's persona was most like that of Charlton Heston, another great American icon. Heston, now denigrated as the Protestant "square," epitomized the ancient value of the Republic. A kind of Puritan king. His contemporaries among the disdainful urban intelligentsia just did not understand the appeal of his home-grown nobility. Heston's film roles required his character to exercise control, control, and more control until he broke under the persistent goading of his leading lady. She, rightly so, wanted to divert some of his attention from his Great Vision and narrowly focused principles.

Grace Kelly goaded her leading men with great calculation until she lost self-control and melted into a somewhat frightening spasm of vulnerable passion. For her, frigidity was a challenge, not a way of life. With this surprise she conquered her leading men.

As an actress she grew in confidence in every role following her first appearance in Henry Hathaway's Fourteen Hours (1951). She was only a pretty stick of a girl in her next film, Zinnemann's High Noon (1952). But she eventually rose to the complete finesse of her tipsy Philadelphia debutante in Charles Walter's High Society (1956), delivering more nuances than Hepburn had done in the same role in the thirties. Her attempts at "tragedy" misfired. She was never convincing slumping around in old clothes and bruised eyes as the martyred wife in the neo-realistic confusion of George Seaton's The Country Girl (1954). But as a comedienne leading lady, she was on par with Lombard and Loy.

Grace Kelly was doubly fortunate in her film career; all her films are still considered entertaining and consequently are all still available in the video stores. The one exception is her last film, Charles Vidor's The Swan (1956), which is unobtainable in a number of countries due to obscure copyright technicalities. Her three Hitchcock films are particularly in demand.

It is New York during a heat wave in Rear Window (1954) and the actress presents herself as a fresh bouquet in her everyday Marie Antoinette Dior dresses. She sets her sights on roving war photographer James Stewart who is disabled in his apartment with a broken leg. His mind and binoculars are trained on the lady next door who loves too well and is murdered for her pains. Kelly's Irish logic convinces him that he must marry her to protect her from a similar fate.

In Dial M For Murder (1954), the perfect Grace is introduced as an English county adulteress. Shocking, but it really is all right because she is the intended victim of her swinish husband's attempt at a perfect murder. She does journeyman's work, but performs an adorable twist-of-fate murder scene in her beautiful negligee. The film concentrates on Ray Milland's brilliant portrait of a conscienceless cad and the mechanics of unravelling his perfect plot.

To Catch A Thief (1956) is the game, set, and match film of all time. Cary Grant and Grace Kelly prowl and sniff around each other like two sleek panthers. They purr and hiss double-entendres which still titillate and raise eyebrows. A peerless match of opponents, their eventual capitulation is a draw. Jesse Royce Landis adds to the exceptional quality of the casting, playing the gutsy robber-baron, widow mother. She continually coaches her daughter's pursuit and surrender to her prey, Grant.

High Society (1956) falls into the musical section. It is a remake of the classical comedy The Philadelphia Story (1949) which starred Katharine Hepburn, Cary Grant, and James Stewart. Grace equals and at time surpasses Hepburn as the tipsy socialite about to marry the wrong man when her first husband arrives on the scene with other ideas. She holds her own with a snappy Frank Sinatra as well as that ultimate laid-back pro, Bing Crosby.

Kelly's adventure films are still fascinating. John Ford's Mogambo (1953) is a remake of that torrid film of the thirties, Red Dust (1932), which starred Gable, Jean Harlow, Mary Astor, and Africa. Africa is still 
compelling but Gable, playing his original role, had entered his straight-character period. He had lost the cynical edge of the cheap rounder which had made him dynamic in the thirties. Ava Gardner's "lady of easy virtue" à la Harlow is short on the easy and too long on virtue. This distorts the intended contrast between the two women because Kelly appears like a primly disguised hand grenade. Failing to ignite the interest of the two gentlemen, she takes off for the jungles of South America where she lights fire crackers with Stewart Granger in Andrew Marton's Green Fire (1954), a comedy about emeralds, coffee and terrorists.

To change a theme, our star was off to the Korean War in Mark Robson's The Bridges of Toko-ri (1954) as the wife of U.S. Navy pilot William Holden. This is a straightforward propaganda film, for lovers of photogenic aircraft carriers and their planes. Grace is lectured by Admiral Fredric March that she must never embarrass her husband, his uniform, the U.S. Navy, or the American flag. Hers is not to reason why, hers is to be the perfect aide-de-camp to one of America's new paladins abroad.

Two of her films were Academy Award winners for the male leads. In the famous High Noon she plays the too dainty Quaker bride to the weary and melancholy Gary Cooper's town marshal. She ultimately learns to shoot to kill in order to protect her man. High Noon is still a book example of a tight, concise script and equally concise production values.

The actress was miscast in The Country Girl (1954) as mournful Bing Crosby's self-appointed martyr wife, frumping around in old cardigans and spectacles. This now dated film is a confusion of Clifford Odets' rhetoric and tepid neo-realism. Grace loyally sticks with her alcoholic star husband Crosby instead of running off with brisk Bill Holden. He is left clutching a bottle. The lady has created another alcoholic but has remained true-blue to the concept of wife.

Grace Kelly's last film was the Ruritanian romance The Swan (1956). She plays pleasingly with Louis Jourdan and conveys a saint-like quality of sacrifice and blissful beatitude as she enters the gilded cage of marriage to the prince. As a princess she will have the perpetual duty to demonstrate the devotion needed to be a Great and Good Wife and never to embarrass her husband and liege lord.

The Princess Grace became a true queen in the best role she ever had. She was set apart from the Dolce Vita of the Riviera and Rome of the time. She had found her true vocation in real life as well as on the screen and her fealty demonstrated to an adoring world that the new American Imperial order could be trusted. Caesar's wife had ventured to the Old World as a gift from the aging Republic. 